\title{
Synthesis, Characterization and Application of Polypyrrole Functionalized Nanocellulose for the Removal of Cr(VI) from Aqueous Solution
}

\author{
Norah Salem Alsaiari ${ }^{1}\left(\mathbb{D}\right.$, Khadijah Mohammedsaleh Katubi ${ }^{1, *(\mathbb{D})}$, Fatimah Mohammed Alzahrani ${ }^{1, *} \mathbb{0}$, \\ Abdelfattah Amari ${ }^{2,3, *(\mathbb{D})}$, Haitham Osman ${ }^{2}$ (D), Faouzi Ben Rebah ${ }^{4}$ (D) and Mohamed A. Tahoon ${ }^{5,6}$ (D) \\ 1 Chemistry Department, College of Science, Princess Nourah Bint Abdulrahman University, \\ Riyadh 11671, Saudi Arabia; nsalsaiari@pnu.edu.sa \\ 2 Department of Chemical Engineering, College of Engineering, King Khalid University, \\ Abha 61411, Saudi Arabia; haman@kku.edu.sa \\ 3 Research Laboratory of Energy and Environment, Department of Chemical Engineering, \\ National School of Engineers, Gabes University, Gabes 6072, Tunisia \\ 4 Higher Institute of Biotechnology of Sfax (ISBS), Sfax University, P.O. Box 263, Sfax 3000, Tunisia; \\ benrebahf@yahoo.fr \\ 5 Department of Chemistry, College of Science, King Khalid University, P.O. Box 9004, \\ Abha 61413, Saudi Arabia; tahooon_87@yahoo.com \\ 6 Chemistry Department, Faculty of Science, Mansoura University, Mansoura 35516, Egypt \\ * Correspondence: kmkatubi@pnu.edu.sa (K.M.K.); fmalzahrani@pnu.edu.sa (F.M.A.); \\ abdelfattah.amari@enig.rnu.tn (A.A.)
}

check for

updates

Citation: Alsaiari, N.S.; Katubi, K.M.; Alzahrani, F.M.; Amari, A.; Osman, H.; Rebah, F.B.; Tahoon, M.A. Synthesis, Characterization and Application of Polypyrrole Functionalized Nanocellulose for the Removal of $\mathrm{Cr}(\mathrm{VI})$ from Aqueous Solution. Polymers 2021, 13, 3691. https:// doi.org/10.3390/polym13213691

Academic Editor: Tetyana Budnyak

Received: 7 October 2021

Accepted: 23 October 2021

Published: 26 October 2021

Publisher's Note: MDPI stays neutral with regard to jurisdictional claims in published maps and institutional affiliations.

Copyright: (c) 2021 by the authors. Licensee MDPI, Basel, Switzerland. This article is an open access article distributed under the terms and conditions of the Creative Commons Attribution (CC BY) license (https:// creativecommons.org/licenses/by/ $4.0 /)$.

\begin{abstract}
Heavy metals are toxic substances that pose a real danger to humans and organisms, even at low concentration. Therefore, there is an urgent need to remove heavy metals. Herein, the nanocellulose (NC) was synthesized by the hydrolysis of cellulose using sulfuric acid, and then functionalized using polypyrrole (ppy) through a polymerization reaction to produce polypyrrole/nanocellulose (ppy/NC) nanocomposite. The synthesized nanocomposite was characterized using familiar techniques including XRD, FT-IR, SEM, TEM, and TGA. The obtained results showed a well-constructed nanocomposite with excellent thermal stability in the nano-sized scale. The adsorption experiments showed that the ppy/NC nanocomposite was able to adsorb hexavalent chromium ( $\mathrm{Cr}(\mathrm{VI}))$. The optimum $\mathrm{pH}$ for the removal of the heavy metal was $\mathrm{pH}$ 2. The interfering ions showed minor effect on the adsorption of $\mathrm{Cr}(\mathrm{VI})$ resulted from the competition between ions for the adsorption sites. The adsorption kinetics were studied using pseudo 1st order and pseudo 2nd order models indicating that the pseudo second order model showed the best fit to the experimental data, signifying that the adsorption process is controlled by the chemisorption mechanism. Additionally, the nanocomposite showed a maximum adsorption capacity of $560 \mathrm{mg} / \mathrm{g}$ according to Langmuir isotherm. The study of the removal mechanism showed that $\mathrm{Cr}(\mathrm{VI})$ ions were removed via the reduction of high toxic $\mathrm{Cr}(\mathrm{VI})$ to lower toxic $\mathrm{Cr}(\mathrm{III})$ and the electrostatic attraction between protonated ppy and $\mathrm{Cr}(\mathrm{VI})$. Interestingly, the ppy/NC nanocomposite was reused for $\mathrm{Cr}(\mathrm{VI})$ uptake up to six cycles showing excellent regeneration results. Subsequently, $\mathrm{Cr}(\mathrm{VI})$ ions can be effectively removed from aqueous solution using the synthesized nanocomposite as reusable and cost-effective adsorbent.
\end{abstract}

Keywords: adsorption; cellulose; polypyrrole; nanomaterials; $\mathrm{Cr}(\mathrm{VI})$; water treatment

\section{Introduction}

Heavy metals pollution is becoming a serious environmental problem around the world [1]. Various toxic metals can cause serious problems to human and marine organisms [2]. Among these metals, chromium $(\mathrm{Cr})$ is considered to be one of the most dangerous metals. Cr naturally exists in two oxidation states $\mathrm{Cr}$ (VI) and $\mathrm{Cr}$ (III) [3]. The two oxidation states have different mobilities and poisonousness. $\mathrm{Cr}$ (III) is stated to be 500 times less 
poisonous than $\mathrm{Cr}(\mathrm{VI})$ [4]. At low quantities, $\mathrm{Cr}(\mathrm{III})$ is less hazardous micronutrient and is required for body metabolism [5]. In contrast, $\mathrm{Cr}(\mathrm{VI})$ exhibits a variety of toxic, mutagenic, and carcinogenic effects to humans. It is expected to cause very dangerous chromosomal mutations by modifying DNA transcription steps [6]. Additionally, $\mathrm{Cr}(\mathrm{VI})$ ions can cause gastric, liver, and kidney damage as well as lung cancer [7].

Generally, photography, textile industries, fertilizers production, wood preservation, chrome coating, leather tanning, stainless steel production, and pigment manufacturing are the main sources of $\mathrm{Cr}(\mathrm{VI})$ ions [8]. Thus, the treatment of wastewater generated by these industries is crucial to prevent pollution to make the environment safe and clean. In recent years, the removal of $\mathrm{Cr}(\mathrm{VI})$ ions from wastewaters before their release into the environment has been considered as a major challenge facing scientists. The treatment strategy aims to reduce $\mathrm{Cr}(\mathrm{VI})$ concentrations from water/wastewater to acceptable levels. According to the World Health Organization (WHO), the permitted level of $\mathrm{Cr}(\mathrm{VI})$ ions is $50.0 \mu \mathrm{g} / \mathrm{L}$ for drinking water is $50.0 \mu \mathrm{g} / \mathrm{L}$ [9], while this level is $5.0 \mu \mathrm{g} / \mathrm{L}$ and $200.0 \mu \mathrm{g} / \mathrm{L}$ for underground water and industrial wastewater, respectively, according to European Union [10].

The removal of $\mathrm{Cr}(\mathrm{VI})$ ions from aqueous solutions was achieved using different techniques such as membrane separation, reverse osmosis, solvent extraction, ion exchange, reduction, chemical and electrochemical precipitations, dialysis, and adsorption [11-16]. Among all methods, adsorption is widely used for the removal of $\mathrm{Cr}(\mathrm{VI})$ ions from aqueous solutions due to many reasons such as ease regeneration of adsorbents, high efficiency, simple operation, and cost-effectiveness [17]. However, the using of conventional adsorbents for the removal of $\mathrm{Cr}(\mathrm{VI})$ ions face many problems such as insufficient hydrophilic surface and functional groups that led to secondary contamination besides the low adsorption capacity due to the low surface area [18]. These limitations of conventional adsorbents can be overcome by using nanomaterials (NMs) as adsorbents. NMs have exceptional properties such as high surface area providing high capacity for metal capturing, ease synthesis, simple functionalization, and low cost [19]. However, the using of NMs as adsorbents for the removal of metals from aqueous solutions was associated with poisonous problems [20]. So, eco-friendly NMs such as nanostructured polysaccharide have been recently examined as friendly adsorbents for the removal of metals from aqueous solutions [21,22]. Interestingly, cellulose is one of the most attractive materials useful as adsorbents to remove organic and inorganic pollutants from wastewater. In this context, the developments of the use of nanocellulose for various applications in environmental remediation, such as its use as adsorbent for enhanced and selective capturing of metallic ions, are well documented in the literature [23-25]. However, the breakdown and agglomeration of cellulose in water limits its use as adsorbent. This limitation can be overcome by the chemical modification of cellulose using polymeric material via the $\mathrm{OH}$ groups. This chemical modification of cellulose helps in increasing the adsorption capacity of nanocellulose besides the increasing of adsorbent mechanical strength [26]. Among various polymers, polypyrrole (ppy) has received considerable interest because of its interesting properties (excellent chemical stability, conductivity, biocompatibility, low oxidation potential, easy synthesis, low cost, etc.) and its good compatibility with different nanoparticles. The use of ppy to adsorb pollutants has been reported as adsorbent for the removal of metals. Additionally, ppy was used for the modification of magnetic $\mathrm{Fe}_{3} \mathrm{O}_{4} / \mathrm{SiO}_{2}$ nanocomposite for the enhanced adsorption of Congo red dye and $\mathrm{Cr}(\mathrm{VI})$ ions [27]. However, its use in large scale wastewater treatment processes is limited by its poor processability and lack of mechanical properties. Therefore, the recorded disadvantages can be eliminated by compositing ppy with other materials (biological materials, chemical polymers, agro-industrial wastes, etc.). Interestingly, the ppy is very suitable for the functionalization of nanocellulose due to good ion exchange performance and high chemical stability [28].

Herein, the nanocellulose was synthesized via the hydrolysis of cellulose using sulfuric acid followed by the functionalization of nanocellulose by the ppy polymer to form the 
nanocomposite (ppy/NC). The ppy/NC nanocomposite was characterized using different techniques and examined for the removal of $\mathrm{Cr}(\mathrm{VI})$ ions from water.

\section{Materials and Methods}

\subsection{Chemicals}

Cellulose with high purity was supplied from HiMedia. Sulfuric acid $\left(\mathrm{H}_{2} \mathrm{SO}_{4}\right)$, ammonium persulfate $\left(\left(\mathrm{NH}_{4}\right)_{2} \mathrm{~S}_{2} \mathrm{O}_{8}\right)$, and pyrrole were supplied from Aladdin (Shanghai, China). Hydrochloric acid $(\mathrm{HCl})$ was supplied from Winlab Chemical (India). Potassium dichromate $\left(\mathrm{K}_{2} \mathrm{Cr}_{2} \mathrm{O}_{7}\right)$ was supplied from Sigma-Aldrich (Schnelldorf, Germany). All chemicals were used as received without any modification. Distilled water was used for the preparation of all solutions.

\subsection{Nanocellulose Synthesis}

Nanocellulose (NC) was synthesized as described in the literature [29] with some modifications. Firstly, a colloidal solution of cellulose was prepared by suspending $20.0 \mathrm{~g}$ of cellulose powder in water followed by hydrolysis process in which the colloidal solution was treated by $60 \mathrm{~mL}$ of $65.0 \%$ sulfuric acid with continuous stirring for $4.0 \mathrm{~h}$ at a temperature of $40^{\circ} \mathrm{C}$. Then, the suspension was centrifuged for $10 \mathrm{~min}$ at $8000 \times \mathrm{g} \mathrm{rpm}$ followed by dialysis to remove the excess of acid. Then, the suspension was dialyzed against deionized water using membranes of 12,000-14,000 Da molecular weight cutoff until the neutral $\mathrm{pH}$ value was achieved. The obtained suspension was finally ultra-sonicated for $45 \mathrm{~min}$ in an ice bath then stored at a temperature of $4{ }^{\circ} \mathrm{C}$. Subsequently, the suspension was ready to be used in the next step.

\subsection{Synthesis of Nanocellulose/Polypyrrole Nanocomposite}

Firstly, the polypyrrole was synthesized via the polymerization of pyrrole $(1.35 \mathrm{~mL}$ of pyrrole in $200 \mathrm{~mL}$ of water) by using $\left(\mathrm{NH}_{4}\right)_{2} \mathrm{~S}_{2} \mathrm{O}_{8}(40.0 \mathrm{~mL}$ of $0.15 \mathrm{M})$ with continuous stirring until the color changed from white to black. The pyrrole was mixed with the suspension solution of nanocellulose under sonication process for $40 \mathrm{~min}$ at $3{ }^{\circ} \mathrm{C}$ using a tip sonicator at a fixed power of $30 \mathrm{~W}$. Then, the mixture was reserved for half-hour at a temperature of $3.0^{\circ} \mathrm{C}$ followed by the removal of the top layer from the mixture. Finally, the lyophilization at $-80^{\circ} \mathrm{C}$ and $20 \mathrm{~Pa}$ besides the solvent exchange with $t$-butanol was used to get the powder of ppy/NC nanocomposite. The obtained nanocomposite was stored at room temperature until use for characterization and application.

\subsection{Adsorption Experiments}

The adsorption experiments were conducted by mixing the solution of $\mathrm{Cr}(\mathrm{VI})$ with the adsorbent at certain conditions of initial concentration, adsorbent dosage, contact time, and $\mathrm{pH}$ in shaker at $200 \mathrm{rpm}$. After each adsorption experiment, the adsorbent was separated using a $0.45 \mu \mathrm{m}$ filter and the remaining solution was examined for the presence of $\mathrm{Cr}(\mathrm{VI})$ ions using UV spectrophotometer $\left(\lambda_{\max }=540 \mathrm{~nm}\right)$ after a complex formation between chromium ions and 1,5-diphenylcarbazide. To study the $\mathrm{pH}$ effect on the adsorption, $60 \mathrm{~mL}$ of $\mathrm{Cr}(\mathrm{VI})$ solution $(100 \mathrm{mg} / \mathrm{L})$ was mixed with $15 \mathrm{mg}$ of adsorbent at different $\mathrm{pH}$ values, ranging from 2.0 to 8.0. Additionally, the removal efficiency of $\mathrm{Cr}(\mathrm{VI})$ ions was determined in the presence of competing ions $\left(\mathrm{NaCl}, \mathrm{Ca}^{2+}, \mathrm{Zn}^{2+}, \mathrm{CO}_{3}{ }^{2-}, \mathrm{PO}_{4}{ }^{3-}\right.$, and $\left.\mathrm{SO}_{4}{ }^{2-}\right)$ added at $0.1 \mathrm{M}$. To study the adsorption kinetics, $300 \mathrm{~mL}$ of $\mathrm{Cr}(\mathrm{VI})$ ions solutions with different initial concentrations ranged from $100 \mathrm{mg} / \mathrm{L}$ to $200 \mathrm{mg} / \mathrm{L}$ were mixed with $75 \mathrm{mg}$ of adsorbent at a $\mathrm{pH}$ of 2. To study the adsorption isotherm, $\mathrm{Cr}(\mathrm{VI})$ ions solutions with different initial concentrations ranged from $50 \mathrm{mg} / \mathrm{L}$ to $300 \mathrm{mg} / \mathrm{L}$ were mixed with the adsorbent at $\mathrm{pH}$ of 2 . The adsorption capacity $\left(\mathrm{q}_{\mathrm{e}}\right)$ of the adsorbent was calculated using Equation (1).

$$
\mathrm{q}_{\mathrm{e}}=\left(\left(\mathrm{C}_{\mathrm{o}}-\mathrm{C}_{\mathrm{e}}\right) / \mathrm{m}\right) \times \mathrm{V},
$$


where $\mathrm{C}_{\mathrm{o}}, \mathrm{C}_{\mathrm{e}}, \mathrm{m}$, and $\mathrm{V}$ denote the initial concentration $(\mathrm{mg} / \mathrm{L})$, equilibrium concentration $(\mathrm{mg} / \mathrm{L})$, the mass of adsorbent $(\mathrm{g})$, and volume of the solution, respectively. The removal percentage (\%) was calculated using Equation (2).

$$
\operatorname{Removal}(\%)=\left(\mathrm{C}_{\mathrm{o}}-\mathrm{C}_{\mathrm{e}} / \mathrm{C}_{\mathrm{o}}\right) \times 100
$$

Moreover, the reusability of ppy/NC nanocomposite for the removal of $\mathrm{Cr}(\mathrm{VI})$ ions was studied up to five successive cycles using $1 \mathrm{M} \mathrm{HCl}$ as eluent. In each cycle, $60 \mathrm{~mL}$ of metallic ions solution was mixed with $15.0 \mathrm{mg}$ of the adsorbent and agitated for 1 day followed by the collection of the adsorbent. Then, the adsorbent was regenerated using the eluent solution for $1.0 \mathrm{~h}$. After that, the adsorbent was washed using water until neutral $\mathrm{pH}$ and subsequently, the adsorbent was ready for the next adsorption-desorption cycle. For errors determination, all experiments were done triplicate.

\section{Results and Discussion}

\subsection{The Characterization of ppy/NC Nanocomposite}

The synthesized materials including NC, ppy, and ppy/NC nanocomposite were characterized using the familiar techniques (FT-IR, XRD, TGA, SEM, and TEM). For the determination of functional groups, FT-IR spectra were shown in Figure 1a. According to Figure 1a, the synthesized NC showed the characteristic cellulose absorption bands like the peaks at $1058 \mathrm{~cm}^{-1}, 2896 \mathrm{~cm}^{-1}$, and $3346 \mathrm{~cm}^{-1}$ that are attributed to the stretching vibrations of $\mathrm{C}-\mathrm{O}-\mathrm{C}, \mathrm{CH}_{2}$, and $\mathrm{OH}$, respectively [30].

However, the FT-IR of ppy/NC nanocomposite showed only the appearance of ppy representative peaks like band of $\mathrm{N}-\mathrm{H}$ wagging at $850 \mathrm{~cm}^{-1}, \mathrm{C}-\mathrm{H}$ in-plane bending at $966 \mathrm{~cm}^{-1}$, and C-H out-plane bending at $1035 \mathrm{~cm}^{-1}$ [31,32]. Additionally, the peak at $1166 \mathrm{~cm}^{-1}$ is attributed to the pyrrole ring breathing while the peak at $1306 \mathrm{~cm}^{-1}$ is attributed to $\mathrm{C}-\mathrm{N}$ in-plane deformation. Additionally, the stretching vibrations of $\mathrm{C}-\mathrm{N}$ and $\mathrm{C}-\mathrm{C}$ bonds were represented by the peaks at $1457 \mathrm{~cm}^{-1}$ and $1555 \mathrm{~cm}^{-1}$, respectively. It is clear that the ppy chain vibrations were affected by the H-bond formation between $\mathrm{NH}$ groups of pyrrole ring and $\mathrm{OH}$ groups of $\mathrm{NC}$ that caused blue shift of peaks compared to the ppy peaks [33]. To study the crystallinity of the synthesized materials, XRD pattern was performed as shown in Figure 1b. According to Figure 1b, cellulose showed the appearance of major three peaks at angle of $2 \theta=34.05,16.45$, and 22.84. From the diffractogram of ppy and ppy/NC, there was a slight difference at $2 \theta=22.84$ due to the overlap of ppy peak [34]. Additionally, the cellulose crystalline order was not affected by the hydrolysis reaction using sulfuric acid [35]. The amorphous nature of the nanocomposite was confirmed from the amorphous region at $2 \theta=22.84$ that is related to ppy as indicated from XRD of pure ppy [36]. To study the thermal stability of synthesized materials, thermogravimetric analysis (TGA) of materials was conducted by heating the materials up to $600{ }^{\circ} \mathrm{C}$ in argon gas atmosphere as shown in Figure 1c. According to Figure 1c, ppy showed a weight loss of $6 \%$ when the temperature raised to $100{ }^{\circ} \mathrm{C}$ due to the evaporation of water content. However, the ppy/NC nanocomposite showed weight loss of $4 \%$ when the temperature raised to $200{ }^{\circ} \mathrm{C}$ due to the evaporation of water residues. At $225^{\circ} \mathrm{C}$, there was a sharp weight loss resulting from thermal decomposition of the pyrolysis of NC. When the temperature was raised to $350^{\circ} \mathrm{C}$, ppy/NC showed a small weight loss due to the decomposition of organic matter of the nanocomposite (cellulose and polypyrrole). Subsequently, the decomposition of organic matter was started above $225^{\circ} \mathrm{C}$ and completed at $600{ }^{\circ} \mathrm{C}(53 \% \mathrm{wt})$. The TGA results indicated the high thermal stability of the synthesized ppy/NC nanocomposite. We can conclude that the combination between ppy and cellulose enhances the composite thermal stability. Additionally, Figure $1 \mathrm{~d}$ showed the zeta potential measurement of the synthesized ppy/NC nanocomposite. According to Figure 1d, the isoelectric point occurred at a value below 6 . This point is the zero charge, below which the protonation of nitrogen centers was achieved which eased the attraction between cations and anions. 


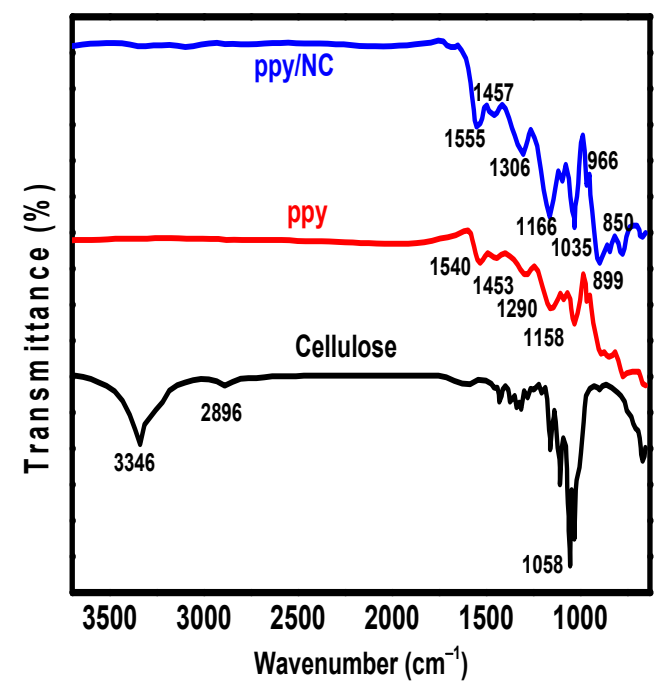

(a)

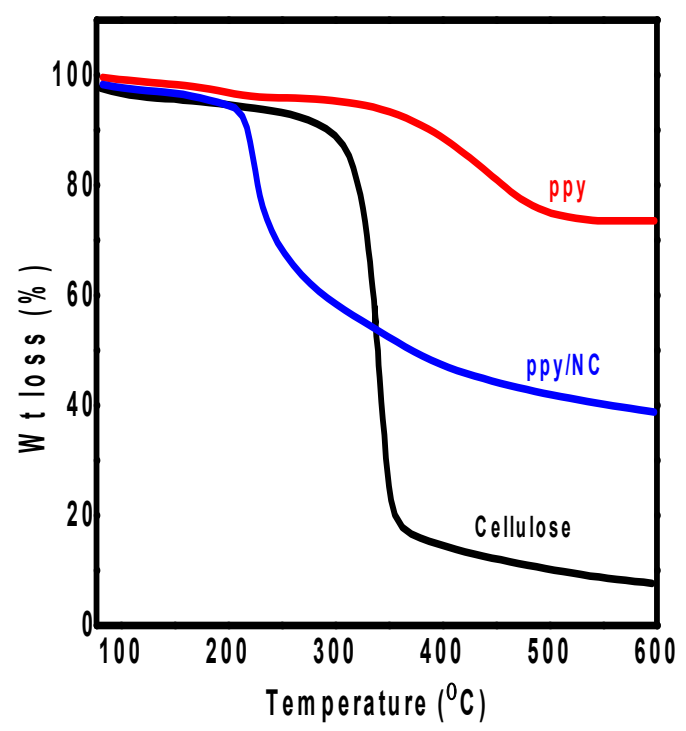

(c)

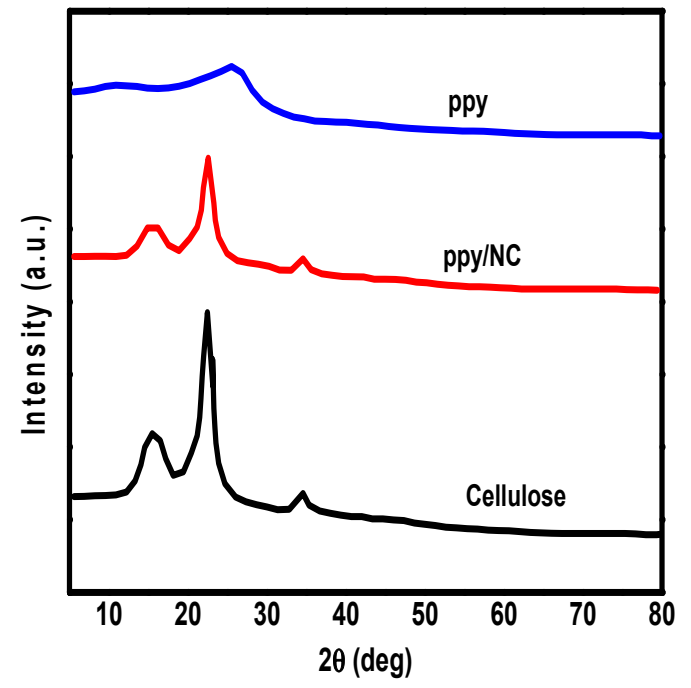

(b)

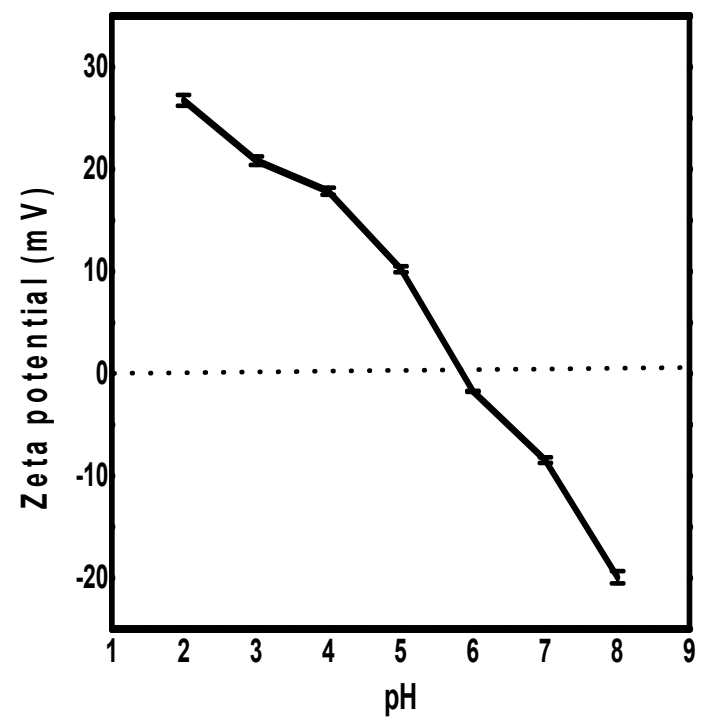

(d)

Figure 1. FT-IR (a) XRD (b), TGA (c), and zeta potential at various $\mathrm{pH}(\mathbf{d})$ of the synthesized ppy, cellulose, and ppy/NC nanocomposite.

To study the surface morphology of the nanocomposite, SEM images at different magnification as well as TEM images were carried out (Figure 2). Figure S1 (Supplementary Material) showed the SEM image of unmodified nanocellulose with smooth surface. Figure $2 a, b$ showed the SEM images of ppy/NC nanocomposite at different resolutions. SEM images of ppy/NC nanocomposite indicated the homogenous and uniform appearance of the particles with a spherical-like shape in the range of nanometer that help the capture of more toxic metals due to the high surface area. Comparing the SEM images of NC and ppy/NC nanocomposite, the surface of NC was greatly changed due to the introduction of ppy indicating the successful modification of NC surface.

Figure S2 (Supplementary Material) showed the SEM image of ppy/NC nanocomposite after the adsorption of $\mathrm{Cr}(\mathrm{VI})$ ions. Figure S2 showed that the surface of the nanocomposite became smooth comparing to the nanocomposite surface due to the capturing of metal ions. Figure $2 c$ showed the TEM image of the nanocomposite. According to Figure $2 d$, the nanoparticles of nanocellulose are agglomerated in some parts and separated in the others. Additionally, there is a major uniform distribution of the nanocellulose particles in the 
nanometer range. As concluded from the TEM image, the average size of nanocellulose particles is $40 \mathrm{~nm}$ to $50 \mathrm{~nm}$.

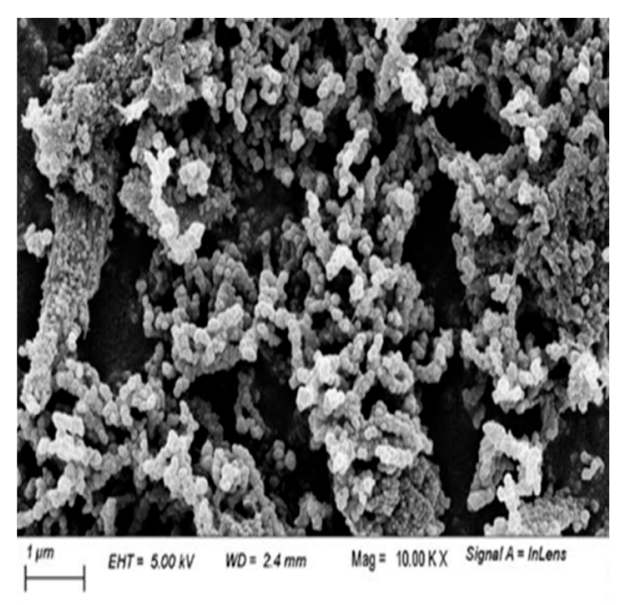

(a)

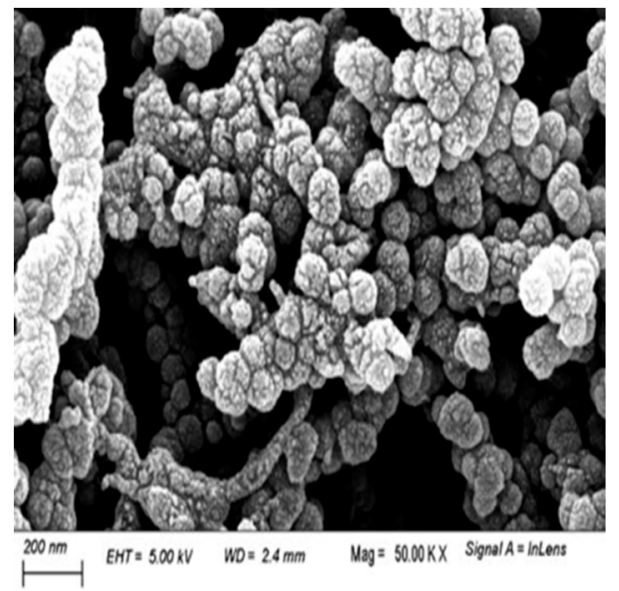

(b)

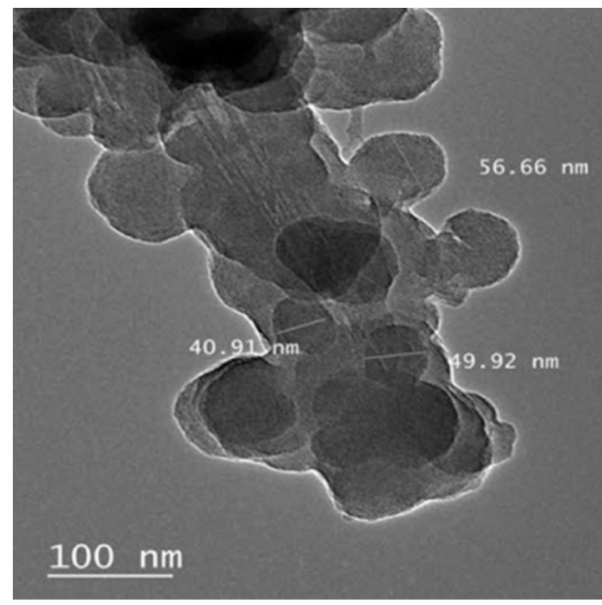

(c)

Figure 2. SEM images at different resolution $(\mathbf{a}, \mathbf{b})$ and TEM image (c) of the synthesized ppy/NC nanocomposite.

\subsection{Effect of $\mathrm{pH}$ on $\mathrm{Cr}(\mathrm{VI})$ Adsorption}

The $\mathrm{pH}$ value of solution is a critical factor affecting the adsorption behavior [37] specially for $\mathrm{Cr}(\mathrm{VI})$ ions. Therefore, the $\mathrm{pH}$ effect on the adsorption of $\mathrm{Cr}(\mathrm{VI})$ on the surface of ppy/NC nanocomposite was studied at $\mathrm{pH}$ ranging from 2 to 8 as shown in Figure 3. According to Figure 3a, the ppy/NC nanocomposite showed the highest removal efficiency for $\mathrm{Cr}(\mathrm{VI})$ ions at $\mathrm{pH}$ value of $2(98 \%)$ while this removal efficiency was decreased gradually by increasing $\mathrm{pH}$ value until reached its lowest efficiency at $\mathrm{pH} 8(32 \%)$. These results of $\mathrm{pH}$ effect on the adsorption could be interpreted according to the ionic behavior of chromium ions at different $\mathrm{pH}$ as illustrated in Figure $3 \mathrm{~b}$.

According to Figure $3 \mathrm{~b}, \mathrm{Cr}_{2} \mathrm{O}_{7}{ }^{2-}$ and $\mathrm{HCrO}_{4}{ }^{-}$are the two oxidation states of chromium ions in the $\mathrm{pH}$ range of 2 to 6 while at higher $\mathrm{pH}$ the chromium phase becomes $\mathrm{CrO}_{4}{ }^{2-}$ [38]. Subsequently, at $\mathrm{pH}$ between 2 and 6, the adsorption of $\mathrm{Cr}(\mathrm{VI})$ ions exists from the electrostatic attraction between the positively charged adsorbent and the negatively charged chromium species. Additionally, the functionalization of nano-cellulose with polypyrrole helps the ion exchange between the adsorbent and chromium species that increases the adsorption efficiency. However, at the $\mathrm{pH}$ value $>6$, there was a great competition between the $\mathrm{OH}^{-}$ions and negatively charged chromium species for the adsorption sites on the adsorbent surface decreasing the adsorption efficiency. From the study of the $\mathrm{pH}$ effect, we can conclude that the $\mathrm{pH}$ increase changed the adsorption of $\mathrm{Cr}(\mathrm{VI})$ ions on the surface of 
ppy/NC nanocomposite from the electrostatic attraction to the electrostatic repulsion. In other words, the adsorption was changed from promotion to competition which would cause the decrease of the removal efficiency.

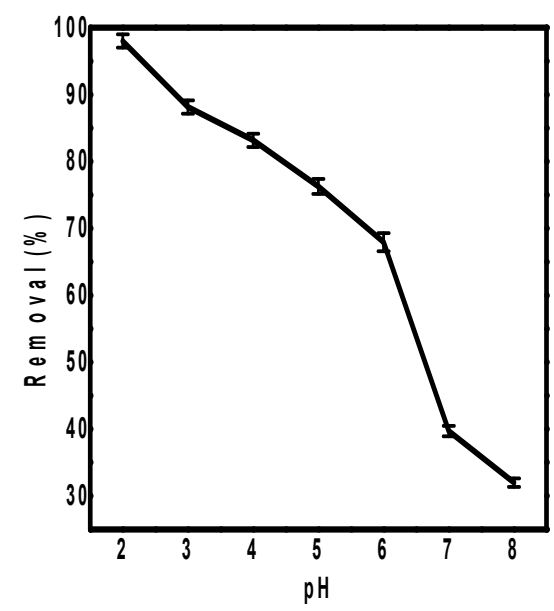

(a)

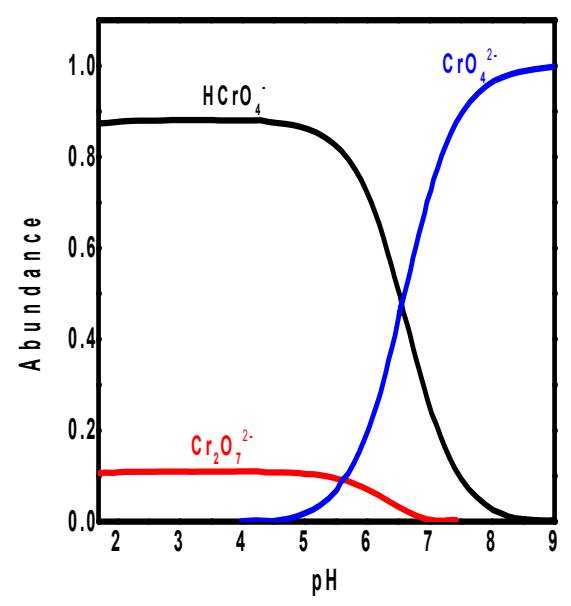

(b)

Figure 3. The effect of $\mathrm{pH}$ on $\mathrm{Cr}(\mathrm{VI})$ adsorption on the ppy/NC surface (a) and the abundance of $\mathrm{Cr}(\mathrm{VI})$ species in aqueous solution at $\mathrm{pH}$ range of 2 to $9(\mathbf{b})$.

\subsection{Effect of Co-Existing Ions on $\mathrm{Cr}(\mathrm{VI})$ Removal}

Different ions such as $\mathrm{NaCl}, \mathrm{Ca}^{2+}, \mathrm{Zn}^{2+}, \mathrm{CO}_{3}{ }^{2-}, \mathrm{PO}_{4}{ }^{3-}$, and $\mathrm{SO}_{4}{ }^{2-}$ may exist in real wastewater and could affect the adsorption of $\mathrm{Cr}(\mathrm{VI})$ ions $[39,40]$. So, the effect of different co-existing ions on the adsorption of $\mathrm{Cr}(\mathrm{VI})$ ions on the surface of ppy/NC nanocomposite was studied in the presence of $0.1 \mathrm{M}$ of each ion as shown in Figure 4.

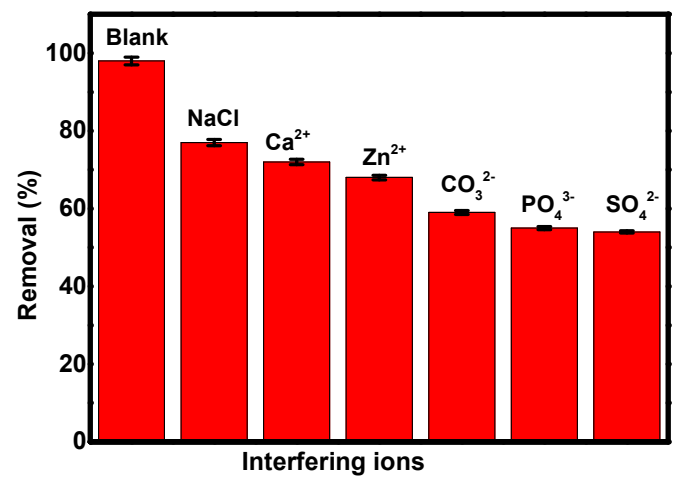

Figure 4. The effect of interfering ions on the $\mathrm{Cr}(\mathrm{VI})$ removal over the surface of ppy/NC nanocomposite.

According to Figure 4, the removal efficiency of $\mathrm{Cr}(\mathrm{VI})$ ions was $98 \%$ in the absence of any interfering ions. Then, this removal efficiency was decreased on the addition of different ions in the order of $\mathrm{NaCl}>\mathrm{Ca}^{2+}>\mathrm{Zn}^{2+}>\mathrm{CO}_{3}{ }^{2-}>\mathrm{PO}_{4}{ }^{3-}>\mathrm{SO}_{4}{ }^{2-}$ with removal efficiencies of $77 \%, 72 \%, 68 \%, 59 \%, 55 \%$, and $54 \%$, respectively. This decrease in the removal efficiency of $\mathrm{Cr}(\mathrm{VI})$ ions was attributed to the competition of interfering ions with chromium ions for the adsorption sites on the adsorbent surface. This order of removal efficiencies is attributed to the differences in the solvated ionic radii between the co-existing ions. Generally, small ions have the ability to reach the adsorption sites easily and compete with toxic metals leading to the drop of the removal efficiency of this metal. According to these results, the ppy/NC nanocomposite can be efficiently used for the removal of hexavalent chromium ions even in the presence of interfering ions. 


\subsection{Adsorption Kinetics}

To study the contact time effect on the adsorption of $\mathrm{Cr}(\mathrm{VI})$ on the surface of ppy/NC nanocomposite, the adsorption capacities were studied at different time intervals from 0 to $35 \mathrm{~h}$ using different initial concentrations of chromium ions as shown in Figure $5 \mathrm{a}$. According to Figure $5 \mathrm{a}$, the first $3 \mathrm{~h}$ showed a rapid increase of the adsorption capacity followed by a slow increase of this capacity until it reached the equilibrium. The rapid increase of adsorption capacity during the first hours could be attributed to the availability of large number of active sites for the uptake of toxic ions [41]. After that, there was a slow increase in the adsorption capacity due to the repulsion between already adsorbed ions on the adsorbent and the other ions until reach the equilibrium at which the adsorbent surface becomes saturated, and the time does not have a significant effect on the adsorption capacity.

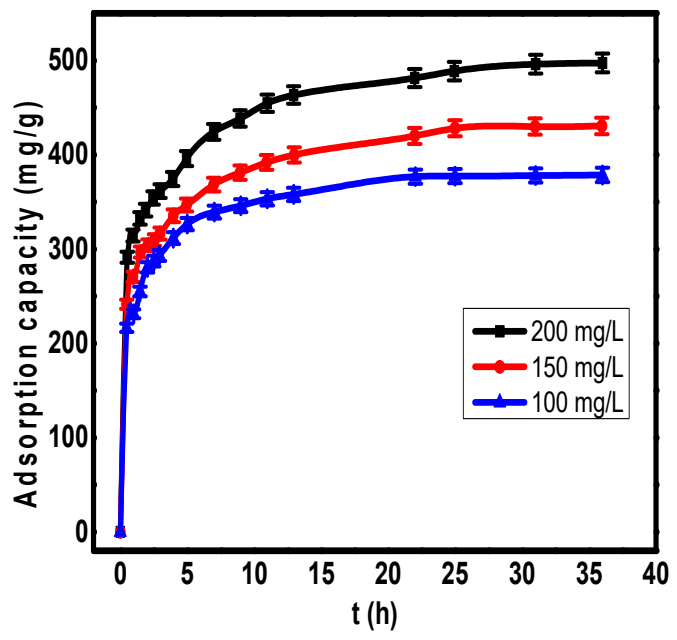

(a)

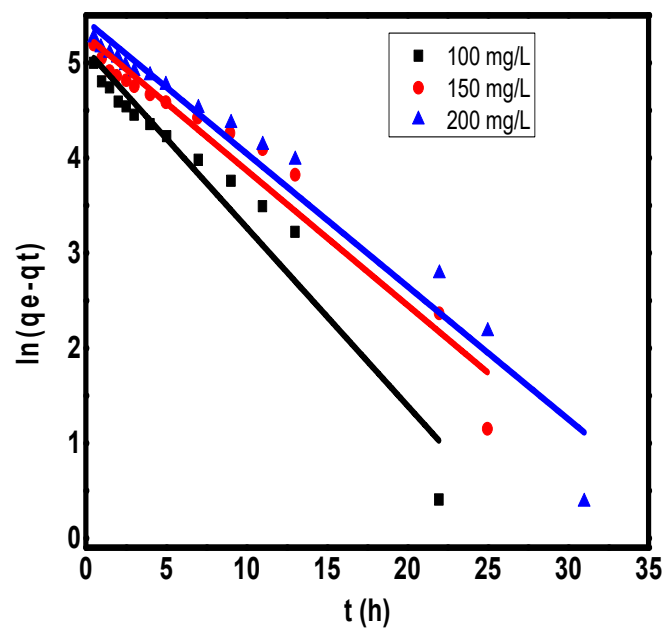

(b)

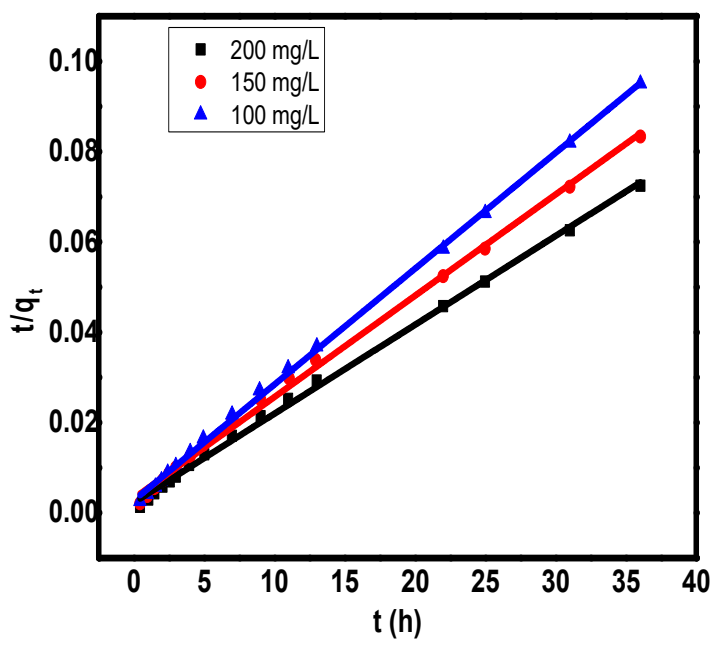

(c)

Figure 5. The effect of contact time at different initial $\mathrm{Cr}(\mathrm{VI})$ concentrations (a), fit of experimental data to pseudo 1st order model (b), and fit of experimental data to pseudo 2nd order model (c) for the removal of $\mathrm{Cr}(\mathrm{VI})$ ions on the surface of ppy/NC nanocomposite. 
The two kinetic models pseudo 1st order and pseudo 2nd order were used to study the adsorption kinetics of $\mathrm{Cr}(\mathrm{VI})$ ions on the surface of ppy/NC nanocomposite. The linear form of pseudo 1st order and pseudo 2nd order is given by Equations (3) and (4), respectively.

$$
\begin{gathered}
\ln \left(\mathrm{q}_{\mathrm{e}}-\mathrm{q}_{\mathrm{t}}\right)=\ln \mathrm{q}_{\mathrm{e}}-\mathrm{k}_{1} \mathrm{t} \\
\mathrm{t} / \mathrm{q}_{\mathrm{t}}=\left(1 / \mathrm{k}_{2} \mathrm{q}_{\mathrm{e}}{ }^{2}\right)+\mathrm{t} / \mathrm{q}_{\mathrm{e}}
\end{gathered}
$$

where $\mathrm{k}_{1}(1 / \mathrm{min})$ and $\mathrm{k}_{2}(\mathrm{~g} / \mathrm{mg} \cdot \mathrm{min})$ are the rate constants for pseudo 1 st order model and pseudo 2nd order model, respectively. The two constants can be calculated from the slop and intercept of the Equations (3) and (4) plots as shown in Figure 5b,c. The kinetic parameters for $\mathrm{Cr}(\mathrm{VI})$ removal on the surface of ppy/NC were listed in Table 1.

Table 1. The parameters of pseudo 1st order and pseudo 2nd order models for the removal of $\mathrm{Cr}(\mathrm{VI})$ on the surface of ppy/NC nanocomposite.

\begin{tabular}{cccccccc}
\hline $\begin{array}{c}\text { Cr(VI) Concentration } \\
(\mathbf{m g} / \mathbf{L})\end{array}$ & \multicolumn{3}{c}{ Pseudo 1st Order } & \multicolumn{3}{c}{ Pseudo 2nd Order } \\
\hline & $\mathbf{q}_{\mathbf{e}}(\mathbf{e x p})(\mathbf{m g} / \mathbf{g})$ & $\mathbf{q}_{\mathbf{e}}(\mathbf{c a l}) \mathbf{( m g / g )}$ & $\mathbf{K}_{\mathbf{1}}$ & $\mathbf{R}^{\mathbf{2}}$ & $\mathbf{q}_{\mathbf{e}}$ (cal) (mg/g) & $\mathbf{K}_{\mathbf{2}}$ & $\mathbf{R}^{\mathbf{2}}$ \\
\hline 100 & 379 & 172 & 0.1880 & 0.9388 & 385.1 & 0.0031 & 0.9993 \\
\hline 150 & 432.1 & 199 & 0.1433 & 0.9499 & 443.2 & 0.0019 & 0.9988 \\
\hline 200 & 496.2 & 233.2 & 0.1395 & 0.9499 & 508.6 & 0.0018 & 0.9979 \\
\hline
\end{tabular}

According to data in Table 1, the correlation coefficient $\left(R^{2}\right)$ value indicated that the adsorption kinetic data were more fitted with the pseudo 2 nd order model than the pseudo 1st order model. This means that the pseudo 2nd order model is more suitable to describe the adsorption mechanism of $\mathrm{Cr}(\mathrm{VI})$ ions on the surface of ppy/NC nanocomposite. These results indicated that the chemical sorption is the essential mechanism of $\mathrm{Cr}(\mathrm{VI})$ removal on the surface of ppy/NC nanocomposite rather than a usual mass transport [42,43]. Additionally, several previous works on the adsorption of $\mathrm{Cr}(\mathrm{VI})$ ions showed the applicability of pseudo 2nd order as a better model for the description of the removal mechanism than other kinetic models [44-47].

\subsection{Adsorption Isotherm}

The interaction between the adsorbent surface and toxic particles can be well-interpreted by the study of the adsorption isotherms. The two isotherms models Freundlich and Langmuir were used to study the experimental data of $\mathrm{Cr}(\mathrm{VI})$ removal on the surface of ppy/NC nanocomposite. Freundlich and Langmuir isotherms can be described in the linearized form according to Equations (5) and (6), respectively.

$$
\begin{gathered}
\ln \mathrm{q}_{\mathrm{e}}=\ln \mathrm{K}_{\mathrm{F}}+1 / \mathrm{n} \ln \mathrm{C}_{\mathrm{e}}, \\
1 / \mathrm{q}_{\mathrm{e}}=\left(1 / \mathrm{q}_{\mathrm{m}} \mathrm{k}_{\mathrm{L}}\right) \mathrm{C}_{\mathrm{e}}+1 / \mathrm{q}_{\mathrm{m}}
\end{gathered}
$$

where $1 / n, K_{F}, K_{L}$, and $q_{m}$ denote the adsorption intensity, Freundlich constant, Langmuir constant, and the maximum adsorption capacity, respectively. It is well-known that Freundlich isotherm suggests the exponential distribution of the adsorption sites as well as the heterogeneous properties of the surface while the Langmuir isotherm suggests the presence of finite amount of identical adsorption sites on the surface of adsorbent as well as the formation of monolayer of adsorbates [48,49]. The fitting of experimental data to Freundlich and Langmuir isotherm models are shown in Figure 6 and their parameters were tabulated in Table 2. The Freundlich and Langmuir parameters were calculated by the plot of $\ln q_{e}$ against $\ln C_{e}$ and $C_{e} / q_{e}$ against $C_{e}$, respectively. According to the results, $1 / n$ value is less than 1 indicating the favorable adsorption of $\mathrm{Cr}(\mathrm{VI})$ on the surface of ppy/NC nanocomposite $[50,51]$. 


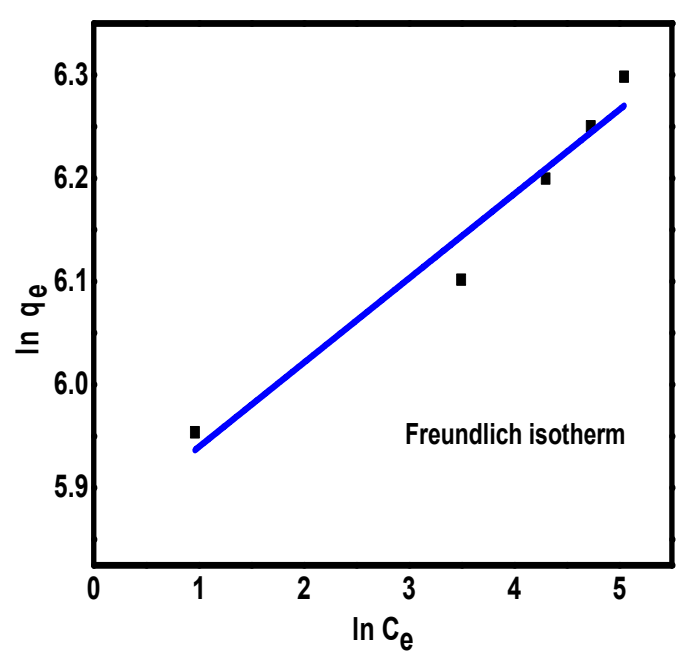

(a)

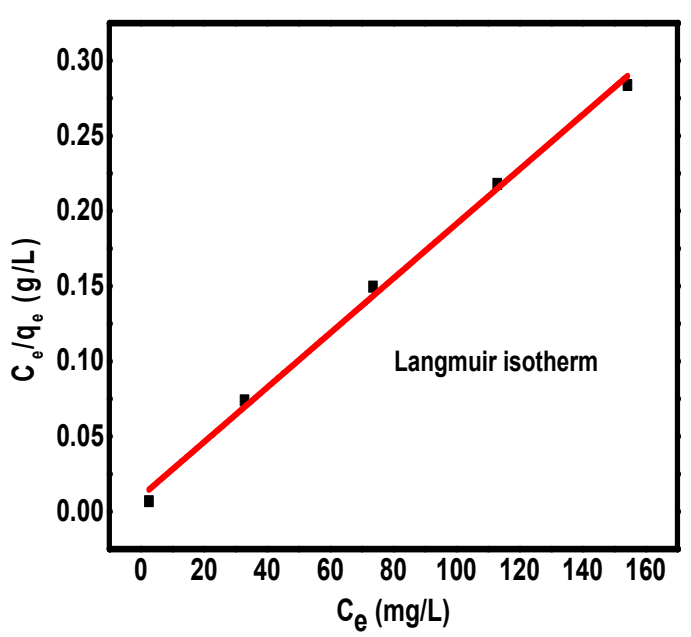

(b)

Figure 6. The fit of experimental data to Freundlich isotherm (a) and Langmuir isotherm (b) for the removal of $\mathrm{Cr}(\mathrm{VI})$ ions on the surface of ppy/NC nanocomposite.

Table 2. The parameters of Freundlish and Langmuir isotherm models for the removal of $\mathrm{Cr}(\mathrm{VI})$ on the surface of ppy/NC nanocomposite.

\begin{tabular}{cccccc}
\hline & Langmuir & & \multicolumn{3}{c}{ Freundlich } \\
\hline $\mathbf{q}_{\mathbf{m}}(\mathbf{m g} / \mathbf{g})$ & $\mathbf{K}_{\mathbf{L}}$ & $\mathbf{R}^{\mathbf{2}}$ & $\mathbf{K}_{\mathbf{F}}$ & $\mathbf{1 / n}$ & $\mathbf{R}^{\mathbf{2}}$ \\
\hline 560 & 0.2300 & 0.997 & 350.1 & 0.0941 & 0.949 \\
\hline
\end{tabular}

The values of correlation coefficients $\left(R^{2}\right)$ were 0.948 for Freundlich isotherm and 0.997 for Langmuir isotherm indicated that the adsorption of $\mathrm{Cr}(\mathrm{VI})$ can be better defined by the Langmuir isotherm model. The isotherm results indicated that the capture of $\mathrm{Cr}(\mathrm{VI})$ ions on the surface of ppy/NC nanocomposite was reached via a monolayer adsorption by identical adsorption active sites [52,53]. Moreover, the maximum adsorption capacity of the nanocomposite was reached $560 \mathrm{mg} / \mathrm{L}$ toward $\mathrm{Cr}(\mathrm{VI})$ ions that is considered excellent results when compared to other adsorbents as discussed in the comparative study section.

\subsection{Discussion on the Mechanism of Removal}

To understand the mechanism of the removal of $\mathrm{Cr}(\mathrm{VI})$ ions on the surface of ppy/NC nanocomposite very well, XPS spectra of the nanocomposite before and after adsorption are reported in Figure 7. Figure 7a shows the scan survey of the nanocomposite. According to Figure $7 \mathrm{a}$, the $\mathrm{C} 1 \mathrm{~s}, \mathrm{~N} 1 \mathrm{~s}$, and $\mathrm{O} 1 \mathrm{~s}$ peaks appeared at binding energies of $285.0 \mathrm{eV}, 400.0 \mathrm{eV}$, and 532.4, respectively [54]. A peak related to $\mathrm{Cr} 2 \mathrm{p}$ was appeared after the capturing process indicated the uptake of the metal. This peak appeared as a twin attributed to Cr $2 p_{3 / 2}$ and $\mathrm{Cr} 2 \mathrm{p}_{1 / 2}$ at 577.0 and $586.9 \mathrm{eV}$, respectively. The oxygen content of the adsorbed chromium ions made the $\mathrm{C} / \mathrm{O}$ ratio of the composite increased considerably after the adsorption as shown in the $\mathrm{O}$ 1s peak. Additionally, the $\mathrm{N} 1$ s spectra of the nanocomposite were completed before and after the metal uptake as shown in Figure $7 \mathrm{~b}$.

According to Figure $7 \mathrm{~b}, \mathrm{~N}^{+}, \mathrm{NH}-$, and $\mathrm{N}$ - peaks were observed with molar ratios equal to $13.8,28.5$, and $57.7 \%$, respectively. These ratios by the action of strong oxidation of $\mathrm{Cr}(\mathrm{VI})$ were increased to $30.4,24.4$, and $45.2 \%$, respectively. Moreover, the Cr $2 \mathrm{p}$ spectra of the nanocomposite were performed to explain the mechanism of metal removal deeply as shown in Figure 7c. After the adsorption, the nanocomposite showed the appearance of Cr (III) and Cr (VI) peaks with molar ratios of $59.7 \%$ and $40.3 \%$, respectively, meaning that the ppy electrons reduces the hexavalent chromium to the trivalent chromium and the 
adsorption process included both ions. This removal mechanism was described by many previous studies [55-58].

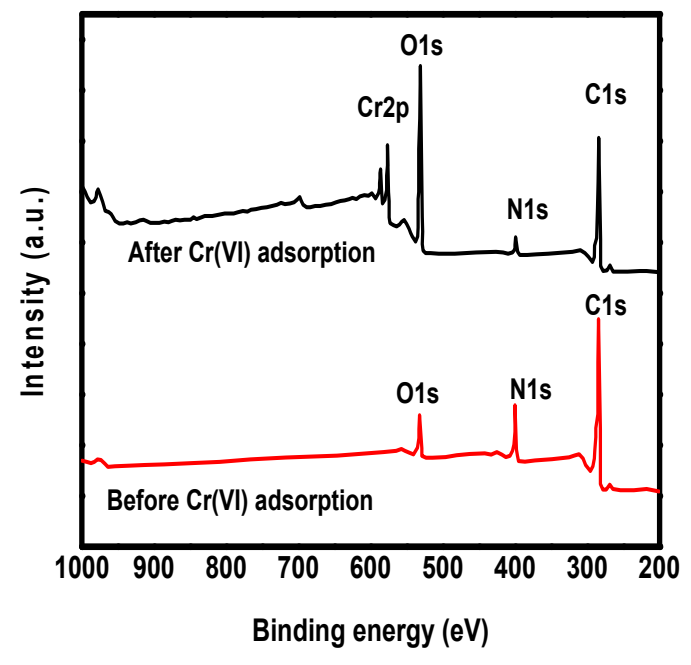

(a)

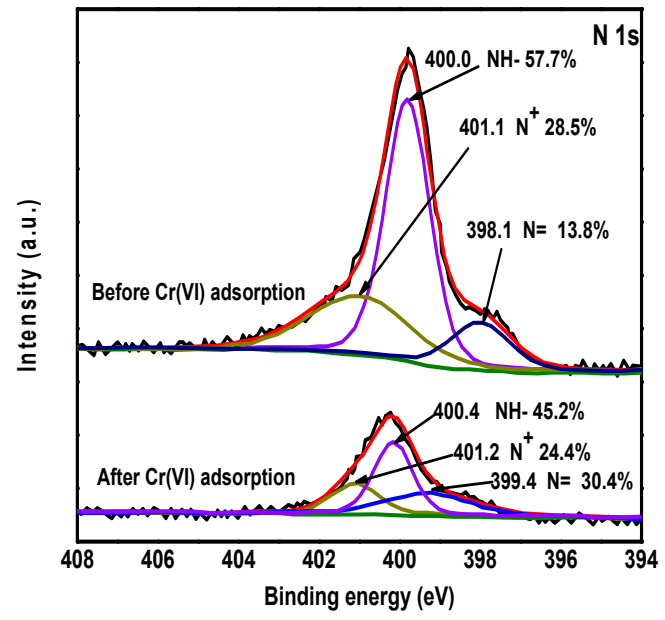

(b)

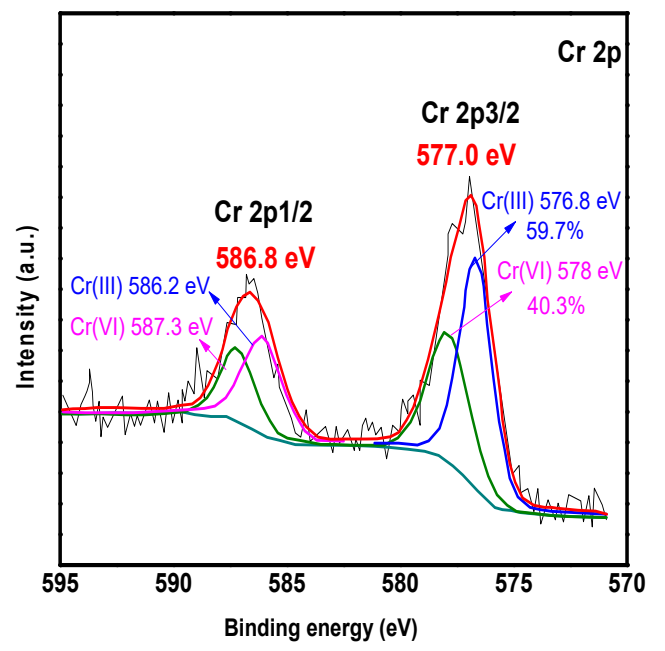

(c)

Figure 7. XPS spectra of ppy/NC nanocomposite with survey scan (a), N 1s spectra (b), and (c) Cr 2p spectra before and after adsorption process.

\subsection{Reusability Study}

For the large-scale application of any adsorbent, its reusability and regeneration must be studied as it is very important economically, and a good reusability may reduce the overall cost of treatment [59]. Subsequently, the reusability of ppy/NC nanocomposite for the removal of $\mathrm{Cr}(\mathrm{VI})$ ions was studied for six successive cycles as shown in Figure 8. Each cycle is consisting of adsorption process followed by desorption process. The adsorbent was agitated with the metallic ion solution followed by the treatment of the adsorbent surface with $1 \mathrm{M}$ of $\mathrm{HCl}$ as eluent. Finally, the adsorbent became ready for the next cycle. 


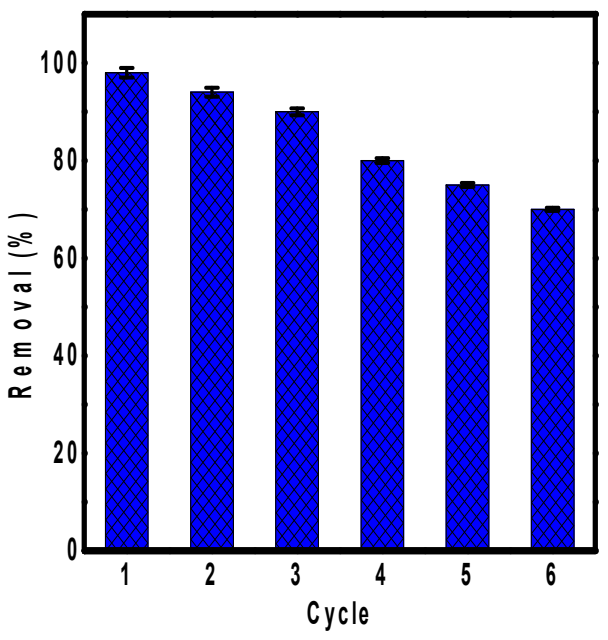

Figure 8. The reusability study of ppy/NC nanocomposite for the removal of $\mathrm{Cr}(\mathrm{VI})$ ions up to six successive cycles.

According to Figure 8, the ppy/NC nanocomposite showed good reusability results for the removal of $\mathrm{Cr}(\mathrm{VI})$ ions up to six cycles. The first cycle showed the highest removal efficiency due to the existence of fresh unused adsorption sites on the surface of adsorbent. After that, the removal efficiency was decreased gradually due to the destroyed nonrenewable sites during each cycle. The last cycle showed a removal efficiency of $70 \%$ indicated the excellent stability of the nanocomposite toward the removal of $\mathrm{Cr}(\mathrm{VI})$ ions. These results indicated the effective regeneration of adsorption sites during the adsorption process which reduces the overall cost of process and encourages the application of the nanocomposite for large scale treatment.

\subsection{Comparative Study}

To assess the performance of ppy/NC as an adsorbent for the removal of $\mathrm{Cr}(\mathrm{VI})$ from aqueous solution, the adsorption capacities of previously reported adsorbents were compared with the present study as listed in Table 3. According to Table 3, the ppy /NC showed an excellent adsorption capacity toward $\mathrm{Cr}(\mathrm{VI})$ ions. This good capacity encourages its use as adsorbent for real samples treatment. Additionally, this adsorbent could be examined for the removal of many other pollutants.

Table 3. The comparison between the removal of $\mathrm{Cr}(\mathrm{VI})$ ions on the surface of ppy/NC nanocomposite and reported studies.

\begin{tabular}{|c|c|c|}
\hline Adsorbent & Adsorption Capacity (mg/g) & Ref. \\
\hline ppy/NC & 560.0 & This study \\
\hline Chitosan-crosslinked-poly(alginic acid) nanohydrogel & 26.42 & {$[60]$} \\
\hline Activated carbon from peanut shell & 16.27 & [61] \\
\hline Polyaniline-coated electrospun adsorbent membrane & 15.09 & [62] \\
\hline Biochar modified with Mg/Al-layered double hydroxide intercalated with EDTA & 38.0 & [63] \\
\hline Sulfuric acid modified leaves & 107.55 & [64] \\
\hline Graphene/SiO ${ }_{2} @ P P y$ nanocomposites & 429.0 & [65] \\
\hline PA6@Mg(OH $)_{2}$ electrospun nanofibers & 296.0 & [66] \\
\hline PAN-NH$H_{2}$ nanofibers & 138.0 & {$[67]$} \\
\hline PAN/polypyrrole core/shell nanofiber mat & 75.0 & {$[68]$} \\
\hline Ammonium-functionalized cellulose nanofibers & 18.0 & [69] \\
\hline
\end{tabular}




\section{Conclusions}

In the present study, cellulose was hydrolyzed using sulfuric acid to produce the nanocellulose, and then functionalized using polypyrrole through a polymerization reaction to fabricate a nanocomposite of polypyrrole/nanocellulose (ppy/NC). The familiar techniques were used for the characterization of the nanocomposite. The crystalline nature of the synthesized NC was approved using XRD. Additionally, the nanosized cellulose was approved through SEM images. Thermal analysis study showed the excellent stability of the nanocomposite with a decomposition point at $225^{\circ} \mathrm{C}$. The synthesized nanocomposite was examined for the adsorption of $\mathrm{Cr}(\mathrm{VI})$ ions. The $\mathrm{pH}$ effect on the adsorption of metallic ions was studied showing an optimum at $\mathrm{pH}$ 2.0. Additionally, the effect of interfering ions on the removal efficiency (\%) was studied with minor decrease in the $\mathrm{Cr}(\mathrm{VI})$ removal due to the competition between ions for the adsorption sites. The nanocomposite showed a maximum adsorption capacity of $560 \mathrm{mg} / \mathrm{g}$ according to Langmuir isotherm model. The study of the removal mechanism showed that the hexavalent chromium was removed via two ways of adsorption and reduction which enhanced the performance of the adsorbent. Additionally, the ppy/ $\mathrm{NC}$ adsorbent was reused for the removal of $\mathrm{Cr}(\mathrm{VI})$ ions up to six cycles with excellent regeneration results. The comparative study of ppy/NC nanocomposite with other reported adsorbents confirmed its higher performance for $\mathrm{Cr}(\mathrm{VI})$ uptake. Hopefully, this nanocomposite is an excellent choice for water treatment and should be investigated toward additional pollutants in the near future.

Supplementary Materials: The following are available online at https:/ /www.mdpi.com/article/10 .3390/polym13213691/s1, Figure S1: SEM image of nanocellulose, Figure S2: SEM image of ppy/NC nanocomposite after $\mathrm{Cr}(\mathrm{VI})$ ions adsorption.

Author Contributions: Conceptualization, F.B.R.; methodology, N.S.A.; software, A.A.; validation, N.S.A. and F.M.A.; formal analysis, K.M.K.; investigation, F.M.A. and H.O.; resources, F.B.R.; data curation, F.B.R.; writing—original draft preparation, F.B.R. and H.O.; writing—review and editing, A.A.; visualization, M.A.T.; supervision, M.A.T.; project administration, A.A.; funding acquisition, N.S.A. All authors have read and agreed to the published version of the manuscript.

Funding: This research was funded by Deanship of Scientific Research at King Khalid University. Additionally, this research was funded by the Deanship of Scientific Research at Princess Nourah bint Abdulrahman University through the Fast-track Research Funding Program.

Institutional Review Board Statement: Not applicable.

Informed Consent Statement: Not applicable.

Data Availability Statement: Not applicable.

Acknowledgments: The authors extend their appreciation to the Deanship of Scientific Research at King Khalid University for funding this work through the research groups program under grant number RGP.2/157/42. Additionally, this research was funded by the Deanship of Scientific Research at Princess NourahBint Abdulrahman University through the Fast-track Research Funding Program.

Conflicts of Interest: The authors declare no conflict of interest.

\section{References}

1. Kobielska, P.A.; Howarth, A.J.; Farha, O.K.; Nayak, S. Metal-organic frameworks for heavy metal removal from water. Coord. Chem. Rev. 2018, 358, 92-107. [CrossRef]

2. Amari, A.; Alzahrani, F.M.; Mohammedsaleh Katubi, K.; Alsaiari, N.S.; Tahoon, M.A.; Rebah, F.B. Clay-polymer nanocomposites: Preparations and utilization for pollutants removal. Materials 2021, 14, 1365. [CrossRef]

3. Rahman, Z.; Singh, V.P. The relative impact of toxic heavy metals (THMs)(arsenic (As), cadmium (Cd), chromium (Cr)(VI), mercury $(\mathrm{Hg})$, and lead $(\mathrm{Pb})$ ) on the total environment: An overview. Environ. Monit. Assess. 2019, 191, 1-21. [CrossRef] [PubMed]

4. Benimeli, C.S.; Polti, M.A.; Albarracín, V.H.; Abate, C.M.; Amoroso, M.J. Bioremediation Potential of Heavy Metal-Resistant Actinobacteria and Maize Plants in Polluted Soil. In Biomanagement of Metal-Contaminated Soils; Springer: Berlin/Heidelberg, Germany, 2011; pp. 459-477.

5. Zhan, M.; Yu, H.; Li, L.; Nguyen, D.T.; Chen, W. Detection of hexavalent chromium by copper sulfide nanocomposites. Anal. Chem. 2019, 91, 2058-2065. [CrossRef] [PubMed] 
6. Du, Y.; Zhang, S.; Wang, J.; Wu, J.; Dai, H. Nb2O5 nanowires in-situ grown on carbon fiber: A high-efficiency material for the photocatalytic reduction of Cr (VI). J. Environ. Sci. 2018, 66, 358-367. [CrossRef]

7. Kaušpèdienè, D.; Kazlauskienè, E.; Gefenienè, A.; Binkienè, R. Comparison of the efficiency of activated carbon and neutral polymeric adsorbent in removal of chromium complex dye from aqueous solutions. J. Hazard. Mater. 2010, 179, 933-939. [CrossRef]

8. Dhal, B.; Thatoi, H.; Das, N.; Pandey, B. Chemical and microbial remediation of hexavalent chromium from contaminated soil and mining/metallurgical solid waste: A review. J. Hazard. Mater. 2013, 250, 272-291. [CrossRef]

9. Anirudhan, T.; Nima, J.; Divya, P. Adsorption of chromium (VI) from aqueous solutions by glycidylmethacrylate-grafted-densified cellulose with quaternary ammonium groups. Appl. Surf. Sci. 2013, 279, 441-449. [CrossRef]

10. Di Natale, F.; Erto, A.; Lancia, A.; Musmarra, D. Equilibrium and dynamic study on hexavalent chromium adsorption onto activated carbon. J. Hazard. Mater. 2015, 281, 47-55. [CrossRef]

11. Choudhury, P.R.; Majumdar, S.; Sahoo, G.C.; Saha, S.; Mondal, P. High pressure ultrafiltration CuO/hydroxyethyl cellulose composite ceramic membrane for separation of $\mathrm{Cr}(\mathrm{VI})$ and $\mathrm{Pb}$ (II) from contaminated water. Chem. Eng. J. 2018, 336, 570-578. [CrossRef]

12. Mnif, A.; Bejaoui, I.; Mouelhi, M.; Hamrouni, B. Hexavalent chromium removal from model water and car shock absorber factory effluent by nanofiltration and reverse osmosis membrane. Int. J. Anal. Chem. 2017, 2017, 7415708. [CrossRef] [PubMed]

13. Ying, Z.; Ren, X.; Li, J.; Wu, G.; Wei, Q. Recovery of chromium (VI) in wastewater using solvent extraction with amide. Hydrometallurgy 2020, 196, 105440. [CrossRef]

14. Farooqi, Z.H.; Akram, M.W.; Begum, R.; Wu, W.; Irfan, A. Inorganic nanoparticles for reduction of hexavalent chromium: Physicochemical aspects. J. Hazard. Mater. 2021, 402, 123535. [CrossRef]

15. Peng, H.; Guo, J. Removal of chromium from wastewater by membrane filtration, chemical precipitation, ion exchange, adsorption electrocoagulation, electrochemical reduction, electrodialysis, electrodeionization, photocatalysis and nanotechnology: A review. Environ. Chem. Lett. 2020, 18, 2055-2068. [CrossRef]

16. Jang, E.-H.; Pack, S.P.; Kim, I.; Chung, S. A systematic study of hexavalent chromium adsorption and removal from aqueous environments using chemically functionalized amorphous and mesoporous silica nanoparticles. Sci. Rep. 2020, 10, 1-20. [CrossRef] [PubMed]

17. Alsaiari, N.S.; Amari, A.; Katubi, K.M.; Alzahrani, F.M.; Rebah, F.B.; Tahoon, M.A. Innovative magnetite based polymeric nanocomposite for simultaneous removal of methyl orange and hexavalent chromium from water. Processes 2021, 9, 576. [CrossRef]

18. Hokkanen, S.; Bhatnagar, A.; Repo, E.; Lou, S.; Sillanpää, M. Calcium hydroxyapatite microfibrillated cellulose composite as a potential adsorbent for the removal of Cr (VI) from aqueous solution. Chem. Eng. J. 2016, 283, 445-452. [CrossRef]

19. Siddeeg, S.M.; Amari, A.; Tahoon, M.A.; Alsaiari, N.S.; Rebah, F.B. Removal of meloxicam, piroxicam and Cd ${ }^{+2}$ by $\mathrm{Fe}_{3} \mathrm{O}_{4} / \mathrm{SiO}_{2} /$ glycidyl methacrylate-S-SH nanocomposite loaded with laccase. Alex. Eng. J. 2020, 59, 905-914. [CrossRef]

20. Batley, G.E.; Kirby, J.K.; McLaughlin, M.J. Fate and risks of nanomaterials in aquatic and terrestrial environments. Acc. Chem. Res. 2013, 46, 854-862. [CrossRef]

21. Hammi, N.; El Hankari, S.; Katir, N.; Marcotte, N.; Draoui, K.; Royer, S.; El Kadib, A. Polysaccharide templated biomimetic growth of hierarchically porous metal-organic frameworks. Microporous Mesoporous Mater. 2020, 306, 110429. [CrossRef]

22. Nasrollahzadeh, M.; Sajjadi, M.; Iravani, S.; Varma, R.S. Starch, cellulose, pectin, gum, alginate, chitin and chitosan derived (nano) materials for sustainable water treatment: A review. Carbohydr. Polym. 2021, 251, 116986. [CrossRef] [PubMed]

23. Joseph, B.; Sagarika, V.; Sabu, C.; Kalarikkal, N.; Thomas, S. Cellulose nanocomposites: Fabrication and biomedical applications. J. Bioresour. Bioprod. 2020, 5, 223-237. [CrossRef]

24. Zou, Y.; Zhao, J.; Zhu, J.; Guo, X.; Chen, P.; Duan, G.; Liu, X.; Li, Y. A Mussel-Inspired Polydopamine-Filled Cellulose Aerogel for Solar-Enabled Water Remediation. ACS Appl. Mater. Interfaces 2021, 13, 7617-7624. [CrossRef] [PubMed]

25. Xia, Z.; Li, J.; Zhang, J.; Zhang, X.; Zheng, X.; Zhang, J. Processing and valorization of cellulose, lignin and lignocellulose using ionic liquids. J. Bioresour. Bioprod. 2020, 5, 79-95. [CrossRef]

26. Yang, J.; Ma, C.; Tao, J.; Li, J.; Du, K.; Wei, Z.; Chen, C.; Wang, Z.; Zhao, C.; Ma, M. Optimization of polyvinylamine-modified nanocellulose for chlorpyrifos adsorption by central composite design. Carbohydr. Polym. 2020, 245, 116542. [CrossRef] [PubMed]

27. Alzahrani, F.M.; Alsaiari, N.S.; Katubi, K.M.; Amari, A.; Ben Rebah, F.; Tahoon, M.A. Synthesis of Polymer-Based Magnetic Nanocomposite for Multi-Pollutants Removal from Water. Polymers 2021, 13, 1742. [CrossRef] [PubMed]

28. Mahmud, H.N.M.E.; Huq, A.O.; binti Yahya, R. The removal of heavy metal ions from wastewater/aqueous solution using polypyrrole-based adsorbents: A review. Rsc Adv. 2016, 6, 14778-14791. [CrossRef]

29. Lu, P.; Hsieh, Y.-L. Preparation and characterization of cellulose nanocrystals from rice straw. Carbohydr. Polym. 2012, 87, 564-573. [CrossRef]

30. Cai, M.; Shafi, S.; Zhao, Y. Preparation of compressible silica aerogel reinforced by bacterial cellulose using tetraethylorthosilicate and methyltrimethoxylsilane co-precursor. J. Non-Cryst. Solids 2018, 481, 622-626. [CrossRef]

31. Yuan, X.; Floresyona, D.; Aubert, P.-H.; Bui, T.-T.; Remita, S.; Ghosh, S.; Brisset, F.; Goubard, F.; Remita, H. Photocatalytic degradation of organic pollutant with polypyrrole nanostructures under UV and visible light. Appl. Catal. B Environ. 2019, 242, 284-292. [CrossRef] 
32. Wang, Y.; Zou, B.; Gao, T.; Wu, X.; Lou, S.; Zhou, S. Synthesis of orange-like Fe 3 O 4/PPy composite microspheres and their excellent Cr (VI) ion removal properties. J. Mater. Chem. 2012, 22, 9034-9040. [CrossRef]

33. Xu, J.; Zhu, L.; Bai, Z.; Liang, G.; Liu, L.; Fang, D.; Xu, W. Conductive polypyrrole-bacterial cellulose nanocomposite membranes as flexible supercapacitor electrode. Org. Electron. 2013, 14, 3331-3338. [CrossRef]

34. Yue, Y.; Wang, X.; Han, J.; Yu, L.; Chen, J.; Wu, Q.; Jiang, J. Effects of nanocellulose on sodium alginate/polyacrylamide hydrogel: Mechanical properties and adsorption-desorption capacities. Carbohydr. Polym. 2019, 206, 289-301. [CrossRef]

35. Zhou, Y.; Zhang, M.; Hu, X.; Wang, X.; Niu, J.; Ma, T. Adsorption of cationic dyes on a cellulose-based multicarboxyl adsorbent. J. Chem. Eng. Data 2013, 58, 413-421. [CrossRef]

36. Ford, E.N.J.; Mendon, S.K.; Thames, S.F.; Rawlins, J.W. X-ray diffraction of cotton treated with neutralized vegetable oil-based macromolecular crosslinkers. J. Eng. Fibers Fabr. 2010, 5, 155892501000500102. [CrossRef]

37. Tang, H.; Zhang, S.; Huang, T.; Cui, F.; Xing, B. pH-Dependent adsorption of aromatic compounds on graphene oxide: An experimental, molecular dynamics simulation and density functional theory investigation. J. Hazard. Mater. 2020, 395, 122680. [CrossRef]

38. Zhang, W.; Zhang, L.; Hua, T.; Li, Y.; Zhou, X.; Wang, W.; You, Z.; Wang, H.; Li, M. The mechanism for adsorption of Cr (VI) ions by PE microplastics in ternary system of natural water environment. Environ. Pollut. 2020, 257, 113440. [CrossRef]

39. Yuan, C.; Zhang, Y.; Yao, J.; Liu, Q.; Kong, F.-G. Facile Synthesis of Polyethylene Glycol@ Tannin-Amine Microsphere towards Cr (VI) Removal. Polymers 2021, 13, 1035. [CrossRef] [PubMed]

40. Khan, S.U.; Zaidi, R.; Shaik, F.; Farooqi, I.H.; Azam, A.; Abuhimd, H.; Ahmed, F. Evaluation of Fe-Mg binary oxide for As (III) adsorption-synthesis, characterization and kinetic modelling. Nanomaterials 2021, 11, 805. [CrossRef] [PubMed]

41. Bakhtiari, N.; Azizian, S. Adsorption of copper ion from aqueous solution by nanoporous MOF-5: A kinetic and equilibrium study. J. Mol. Liq. 2015, 206, 114-118. [CrossRef]

42. Liakos, E.V.; Mone, M.; Lambropoulou, D.A.; Bikiaris, D.N.; Kyzas, G.Z. Adsorption evaluation for the removal of nickel, mercury, and barium ions from single-component and mixtures of aqueous solutions by using an optimized biobased chitosan derivative. Polymers 2021, 13, 232. [CrossRef] [PubMed]

43. El Kaim Billah, R.; Khan, M.A.; Wabaidur, S.M.; Jeon, B.-H.; Am, A.; Majdoubi, H.; Haddaji, Y.; Agunaou, M.; Soufiane, A. Chitosan/Phosphate Rock-Derived Natural Polymeric Composite to Sequester Divalent Copper Ions from Water. Nanomaterials 2021, 11, 2028. [CrossRef] [PubMed]

44. Murad, H.A.; Ahmad, M.; Bundschuh, J.; Hashimoto, Y.; Zhang, M.; Sarkar, B.; Ok, Y.S. A remediation approach to chromiumcontaminated water and soil using engineered biochar derived from peanut shell. Environ. Res. 2021, 204, 112125. [CrossRef] [PubMed]

45. Mahmoud, A.; Fawzy, M.; Hosny, G.; Obaid, A. Equilibrium, kinetic, and diffusion models of chromium (VI) removal using Phragmites australis and Ziziphus spina-christi biomass. Int. J. Environ. Sci. Technol. 2021, 18, 2125-2136. [CrossRef]

46. Gao, K.; Li, J.; Chen, M.; Jin, Y.; Ma, Y.; Ou, G.; Wei, Z. ZIF-67 derived magnetic nanoporous carbon coated by poly (mphenylenediamine) for hexavalent chromium removal. Sep. Purif. Technol. 2021, 277, 119436. [CrossRef]

47. Khalil, U.; Shakoor, M.B.; Ali, S.; Ahmad, S.R.; Rizwan, M.; Alsahli, A.A.; Alyemeni, M.N. Selective Removal of Hexavalent Chromium from Wastewater by Rice Husk: Kinetic, Isotherm and Spectroscopic Investigation. Water 2021, 13, 263. [CrossRef]

48. Albadarin, A.B.; Collins, M.N.; Naushad, M.; Shirazian, S.; Walker, G.; Mangwandi, C. Activated lignin-chitosan extruded blends for efficient adsorption of methylene blue. Chem. Eng. J. 2017, 307, 264-272. [CrossRef]

49. Shahnaz, T.; Patra, C.; Sharma, V.; Selvaraju, N. A comparative study of raw, acid-modified and EDTA-complexed Acacia auriculiformis biomass for the removal of hexavalent chromium. Chem. Ecol. 2020, 36, 360-381. [CrossRef]

50. Pete, S.; Kattil, R.A.; Thomas, L. Polyaniline-multiwalled carbon nanotubes (PANI-MWCNTs) composite revisited: An efficient and reusable material for methyl orange dye removal. Diam. Relat. Mater. 2021, 117, 108455. [CrossRef]

51. Zhao, Y.; Yang, H.; Sun, J.; Zhang, Y.; Xia, S. Enhanced Adsorption of Rhodamine B on Modified Oil-Based Drill Cutting Ash: Characterization, Adsorption Kinetics, and Adsorption Isotherm. ACS Omega 2021, 6, 17086-17094. [CrossRef]

52. Verma, M.; Tyagi, I.; Kumar, V.; Goel, S.; Vaya, D.; Kim, H. Fabrication of GO-MnO2 nanocomposite using hydrothermal process for cationic and anionic dyes adsorption: Kinetics, isotherm, and reusability. J. Environ. Chem. Eng. 2021, 9, 106045. [CrossRef]

53. Sintakindi, A.; Ankamwar, B. Uptake of methylene blue from aqueous solution by naturally grown daedalea africana and phellinus adamantinus fungi. ACS Omega 2020, 5, 12905-12914. [CrossRef]

54. Wan, C.; Jiao, Y.; Li, J. Flexible, highly conductive, and free-standing reduced graphene oxide/polypyrrole/cellulose hybrid papers for supercapacitor electrodes. J. Mater. Chem. A 2017, 5, 3819-3831. [CrossRef]

55. Wang, Z.; Wang, Y.; Cao, S.; Liu, S.; Chen, Z.; Chen, J.; Chen, Y.; Fu, J. Fabrication of core@ shell structural Fe-Fe2O3@ PHCP nanochains with high saturation magnetization and abundant amino groups for hexavalent chromium adsorption and reduction. J. Hazard. Mater. 2020, 384, 121483. [CrossRef] [PubMed]

56. Wang, Y.; Zhao, D.; Feng, S.; Chen, Y.; Xie, R. Ammonium thiocyanate functionalized graphene oxide-supported nanoscale zero-valent iron for adsorption and reduction of Cr (VI). J. Colloid Interface Sci. 2020, 580, 345-353. [CrossRef] [PubMed]

57. Ji, Y.; Xu, F.; Zhang, P.; Xu, Y.; Zhang, G. Green synthesis of poly (pyrrole methane)-based adsorbent for efficient removal of chromium (VI) from aqueous solution. J. Clean. Prod. 2021, 293, 126197. [CrossRef] 
58. Lei, C.; Wang, C.; Chen, W.; He, M.; Huang, B. Polyaniline@ magnetic chitosan nanomaterials for highly efficient simultaneous adsorption and in-situ chemical reduction of hexavalent chromium: Removal efficacy and mechanisms. Sci. Total Environ. 2020, 733, 139316. [CrossRef] [PubMed]

59. Sharma, S.; Kumar, A.S.K.; Rajesh, N. A perspective on diverse adsorbent materials to recover precious palladium and the way forward. Rsc Adv. 2017, 7, 52133-52142. [CrossRef]

60. Sharma, G.; Naushad, M.; Ala'a, H.; Kumar, A.; Khan, M.R.; Kalia, S.; Bala, M.; Sharma, A. Fabrication and characterization of chitosan-crosslinked-poly (alginic acid) nanohydrogel for adsorptive removal of $\mathrm{Cr}$ (VI) metal ion from aqueous medium. Int. J. Biol. Macromol. 2017, 95, 484-493. [CrossRef]

61. Al-Othman, Z.A.; Ali, R.; Naushad, M. Hexavalent chromium removal from aqueous medium by activated carbon prepared from peanut shell: Adsorption kinetics, equilibrium and thermodynamic studies. Chem. Eng. J. 2012, 184, 238-247. [CrossRef]

62. Dognani, G.; Hadi, P.; Ma, H.; Cabrera, F.C.; Job, A.E.; Agostini, D.L.; Hsiao, B.S. Effective chromium removal from water by polyaniline-coated electrospun adsorbent membrane. Chem. Eng. J. 2019, 372, 341-351. [CrossRef]

63. Huang, D.; Liu, C.; Zhang, C.; Deng, R.; Wang, R.; Xue, W.; Luo, H.; Zeng, G.; Zhang, Q.; Guo, X. Cr (VI) removal from aqueous solution using biochar modified with $\mathrm{Mg} / \mathrm{Al}$-layered double hydroxide intercalated with ethylenediaminetetraacetic acid. Bioresour. Technol. 2019, 276, 127-132. [CrossRef]

64. Zhang, Y.; Li, M.; Li, J.; Yang, Y.; Liu, X. Surface modified leaves with high efficiency for the removal of aqueous Cr (VI). Appl. Surf. Sci. 2019, 484, 189-196. [CrossRef]

65. Fang, W.; Jiang, X.; Luo, H.; Geng, J. Synthesis of graphene/SiO2@ polypyrrole nanocomposites and their application for Cr (VI) removal in aqueous solution. Chemosphere 2018, 197, 594-602. [CrossRef] [PubMed]

66. Jia, B.-B.; Wang, J.-N.; Wu, J.; Li, C.-J. “Flower-Like” PA6@ Mg (OH) 2 electrospun nanofibers with Cr (VI)-removal capacity. Chem. Eng. J. 2014, 254, 98-105. [CrossRef]

67. Mohamed, A.; Nasser, W.; Osman, T.; Toprak, M.; Muhammed, M.; Uheida, A. Removal of chromium (VI) from aqueous solutions using surface modified composite nanofibers. J. Colloid Interface Sci. 2017, 505, 682-691. [CrossRef] [PubMed]

68. Wang, J.; Pan, K.; He, Q.; Cao, B. Polyacrylonitrile/polypyrrole core/shell nanofiber mat for the removal of hexavalent chromium from aqueous solution. J. Hazard. Mater. 2013, 244, 121-129. [CrossRef]

69. He, X.; Cheng, L.; Wang, Y.; Zhao, J.; Zhang, W.; Lu, C. Aerogels from quaternary ammonium-functionalized cellulose nanofibers for rapid removal of Cr (VI) from water. Carbohydr. Polym. 2014, 111, 683-687. [CrossRef] 